\title{
BEHAVIOR OF MULTISUBSTITUTED HYDROXYAPATITES IN WATER AND SIMULATED BODY FLUID
}

\author{
OANA CADAR ${ }^{\mathrm{a}}$, REKA BALINT ${ }^{\mathrm{b}}$, GHEORGHE TOMOAIA ${ }^{\mathrm{c}, \mathrm{d}}$, \\ DIANA FLOREA ${ }^{\mathrm{b}, \mathrm{e}}$, IOAN PETEAN ${ }^{\mathrm{b}}$, AURORA MOCANU $^{\mathrm{b}}$, \\ OSSI HOROVITZ ${ }^{\mathrm{b}}$, MARIA TOMOAIA-COTISEL ${ }^{\mathrm{b}, \mathrm{d} *}$
}

\begin{abstract}
Nanostructured hydroxyapatite (HAP) and three multiple substituted HAPs, containing Mg, Zn, Sr and Si were synthesized by a wet precipitation method The presence of the HAP lattice as unique crystalline phase was established by XRD and by FTIR spectroscopy. The chemical composition was confirmed by SEM-EDX. The TEM, SEM and AFM imaging showed the morphology of these biomaterials. The elements release in water and in simulated body fluid (SBF) was monitored in time from 1 to 90 days, by using inductively coupled plasma optical emission spectrometry (ICP-OES). The results are important for the future use of these hydroxyapatite biomaterials, as bone substitutes or coatings on metallic implants, able to release essential physiological elements, both in vitro and in vivo, with great impact in orthopedics and dentistry.
\end{abstract}

Keywords: multisubstituted hydroxyapatites, magnesium, zinc, strontium, silicon, ions release, water, SBF

\section{INTRODUCTION}

The increasing application of biomaterials based on synthetic hydroxyapatites (HAPs) as bone substitutes imposes the preparation of

a INCDO INOE 2000, Research Institute for Analytical Instrumentation, 67 Donath Str., RO400293, Cluj-Napoca, Romania

b Babeş-Bolyai University, Faculty of Chemistry and Chemical Engineering, Department of Chemical Engineering, 11 Arany J. Str., RO-400028, Cluj-Napoca, Romania

c Iuliu Hatieganu University of Medicine and Pharmacy, Orthopedics and Traumatology Department, 47 Mosoiu T. Str., RO-400132 Cluj-Napoca, Romania

d Academy of Romanian Scientists, 54 Splaiul Independentei, RO-050094 Bucharest, Romania

e Iuliu Haţieganu University of Medicine and Pharmacy, Faculty of Dentistry, 8 Babeș V. Str., Cluj-Napoca, 400012, Romania

*Corresponding author: mcotisel@chem.ubbcluj.ro 
HAPs with a composition which imitates that of the mineral phase of natural bone [1-3]. Along with calcium and phosphorus, a series of other elements are important in the biological function of the bone

Magnesium is found in bones and teeth. It is implied in bone growth and remodelling by the activation of osteoblast cells [4], while its deficit is related to osteoporosis. Zinc inhibits the osteoclasts [5] and increases the response of osteoblasts [6]; anti-inflammatory [7] and antimicrobial effects [8] of HAP with $\mathrm{Zn}$ were also reported. Strontium is known to regulate bone turnover by increasing the activity of osteoblasts [9] and diminishing bone resorption [9] acting on the osteoclasts [10]. Strontium ranelate is increasingly used in the treatment of osteoporosis [11] Silicon is also implied in the bioactivity of osteoblasts [12,13].

Strontium can substitute calcium in $\mathrm{HAP}, \mathrm{Ca}_{10}\left(\mathrm{PO}_{4}\right)_{6}(\mathrm{OH})_{2}$ in any proportion, even up to $100 \%$ [14]. The substitution of $\mathrm{Mg}^{2+}$ for $\mathrm{Ca}^{2+}$ is more problematic, since the ionic radius of $\mathrm{Mg}^{2+}$ is much lower than that of $\mathrm{Ca}^{2+}$, and the HAP lattice is distorted. There are contradictory assumptions about the limit of subtitution of $\mathrm{Ca}$ by $\mathrm{Mg}$. According to many authors, this limit is $2.46 \mathrm{wt} \% \mathrm{Mg}$ (10 mol\% of Ca substituted by Mg) [15-18], The Mg in excess would be located in the amorphous phase and/or on the crystallite surface, while for higher Mg content a mixture of phases is obtained [19]. For zinc substituted HAPs, the limit of substitution is considered to be $12.4 \mathrm{wt} \% \mathrm{Zn}$ (20 mol\% of Ca substituted by Zn) [20, 21]. As for silicon, the estimated theoretical limit of phosphorus substitution, with conservation of the HAP lattice, would be $5.8 \mathrm{wt} \% \mathrm{Si}$. But experimentally lower limits were found, from 5 down to 3 wt $\%$ Si [e.g. 22, 23].

In the present investigation, multiple substituted HAPs containing the above mentioned elements, were prepared and characterized, and the release of their elements in water, respectively their release and uptake in simulated body fluid (SBF) was studied

\section{RESULTS AND DISCUSSION}

Pure hydroxyapatite (HAP), a complex triple substituted hydroxyapatite, with $\mathrm{Mg}, \mathrm{Zn}$ and $\mathrm{Si}$ (HAPc), and two tetrasubstituted complex hydroxyapatites, containing $\mathrm{Mg}, \mathrm{Zn}, \mathrm{Si}$ and $\mathrm{Sr}$ were prepared. Their compositions are given in Table 1. The theoretical formula in the table were calculated assuming that $\mathrm{Mg}^{2+}, \mathrm{Zn}^{2+}$ and $\mathrm{Sr}^{2+}$ ions partially substitute for $\mathrm{Ca}^{2+}$ ions in the HAP lattice, while $\mathrm{Si}$, as silicate $\mathrm{SiO}_{4}{ }^{4-}$ ions substitutes some of the phosphate, $\mathrm{PO}_{4}{ }^{3-}$ ions, with a corresponding diminution of the number of $\mathrm{OH}^{-}$ions, in order to maintain the electroneutrality of the lattice, according to the general formula: $\mathrm{Ca}_{10-\mathrm{x}-\mathrm{y}-\mathrm{z}} \mathrm{Mg}_{\mathrm{x}} \mathrm{Zn}_{\mathrm{y}} \mathrm{Sr}_{z}\left(\mathrm{PO}_{4}\right)_{6-u}\left(\mathrm{SiO}_{4}\right)_{\mathrm{u}}$. 
Table 1. Composition of HAP and complex HAPs

\begin{tabular}{|l|c|c|l|l|l|l|l|}
\hline \multirow{2}{*}{ Name } & \multicolumn{5}{|c|}{ Composition (wt\%) } & \multirow{2}{*}{ Theoretical formula } \\
\cline { 2 - 6 } & $\mathrm{Ca}$ & $\mathrm{P}$ & $\mathrm{Mg}$ & $\mathrm{Zn}$ & $\mathrm{Sr}$ & $\mathrm{Si}$ & \\
\hline HAP & 39.89 & 18.50 & 0 & 0 & 0 & 0 & $\mathrm{Ca}_{10}\left(\mathrm{PO}_{4}\right)_{6}(\mathrm{OH})_{2}$ \\
HAPc & 37.71 & 18.47 & 1.5 & 0.2 & 0 & 0.2 & $\mathrm{Ca}_{9.36} \mathrm{Mg}_{0.61} \mathrm{Zn}_{0.03}(\mathrm{PO})_{5.93}\left(\mathrm{SiO}_{4}\right)_{0.07}(\mathrm{OH})_{1.93}$ \\
HAPc-Sr5 & 34.34 & 17.97 & 1.5 & 0.2 & 5 & 0.2 & $\mathrm{Ca}_{8.76} \mathrm{Mg}_{0.63} \mathrm{Zn}_{0.03} \mathrm{Sr}_{0.58}\left(\mathrm{PO}_{\mathrm{O}_{5.93}}\left(\mathrm{SiO}_{4}\right)_{0.07}(\mathrm{OH})_{1.93}\right.$ \\
HAPc-Sr10 & 30.98 & 17.46 & 1.5 & 0.2 & 10 & 0.2 & $\mathrm{Ca}_{8.12} \mathrm{Mg}_{0.65} \mathrm{Zn}_{0.03} \mathrm{Sr}_{1.20}(\mathrm{PO} 4)_{5.93}\left(\mathrm{SiO}_{4}\right)_{0.07}(\mathrm{OH})_{1.93}$ \\
\hline
\end{tabular}

\section{Structural and morphological characterization}

The HAP structure, as unique phase present in all samples, was confirmed by XRD investigations. As an example, the XRD pattern for HAPcSr5 is compared in Fig. 1 with the powder diffraction file (PDF) 74-056 for pure HAP. The mean size of crystallites in the samples is about $40 \mathrm{~nm}$ and the degree of crystallinity $40-50 \%$, the highest for pure HAP, the lowest for HAPc.

The FTIR spectrum is also that characteristic for hydroxyapatites, with the absorption bands corresponding to the vibrations of $\mathrm{P}-\mathrm{O}$ bonds in $\mathrm{PO}_{4}$ and of the structural O-H group (Fig. 2 for the example of HAPc- Sr10). With increasing $\mathrm{Sr}$ content, the intensity of the $\mathrm{OH}$ bands decreases, and in the spectrum of HAPc-Sr10, the libration band at about $634 \mathrm{~cm}^{-1}$ appears only as a shoulder (Fig. 2b).

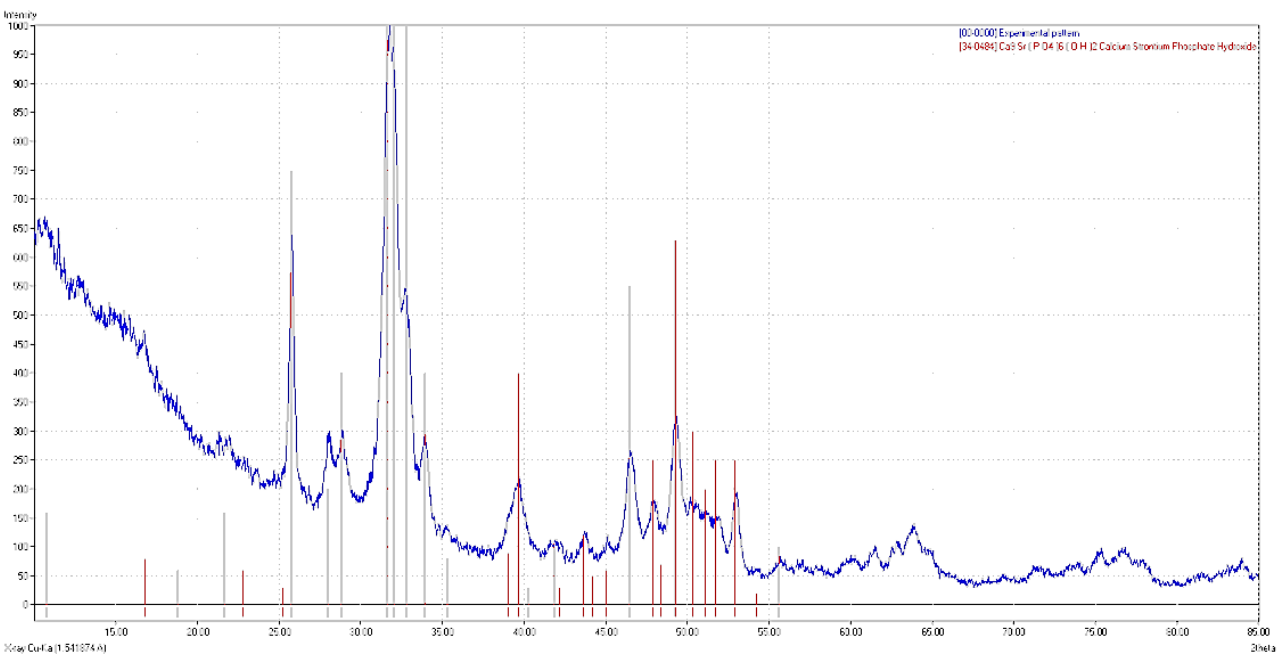

Figure 1. XRD patterns for HAPc-Sr5, compared with PDF 74-0566 for hydroxyapatite 


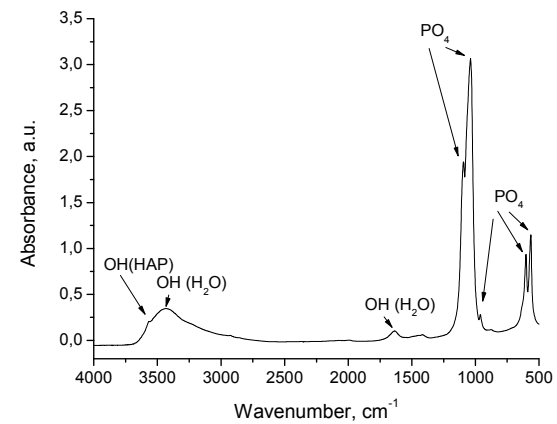

a.

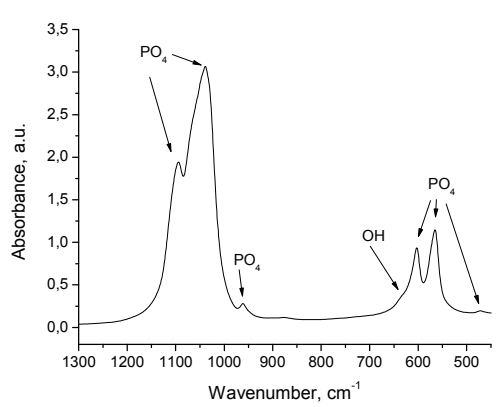

b.

Figure 2. FTIR spectrum for HAPc-Sr10 (a), and detail (b).

The TEM (Fig. 3) and SEM (Fig.4a) images present the morphology of HAP particles. In the EDX spectrum of HAPc-Sr10 (Fig. 4b), the peaks for $\mathrm{Ca}, \mathrm{P}, \mathrm{Mg} . \mathrm{Zn}, \mathrm{Sr}$ and $\mathrm{Si}$ are all visible, along with peaks of gold, which was used to coat the hydroxyapatite particles for SEM imaging.

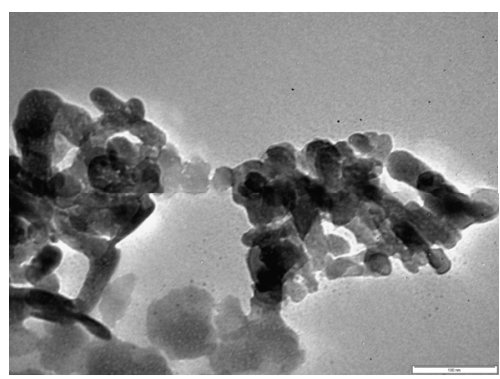

a.

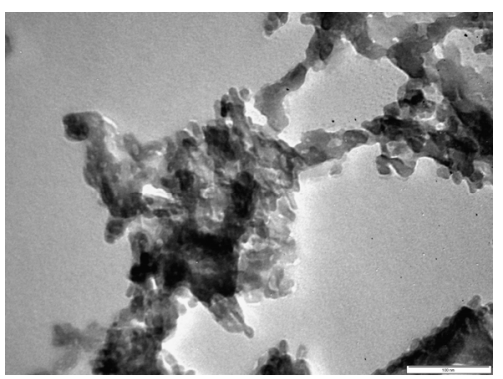

b.

Figure 3. TEM images of HAP (a) and HAPc-Sr10 (b). The bars in the images are $100 \mathrm{~nm}$.

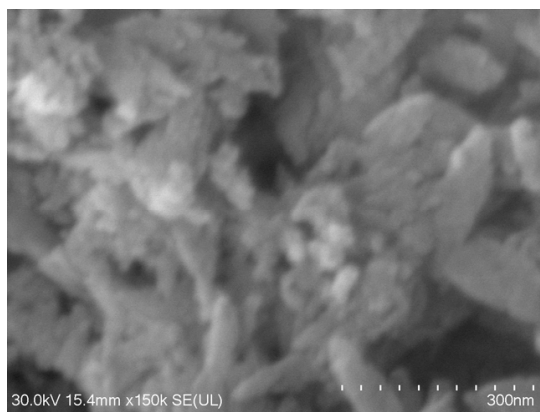

a.

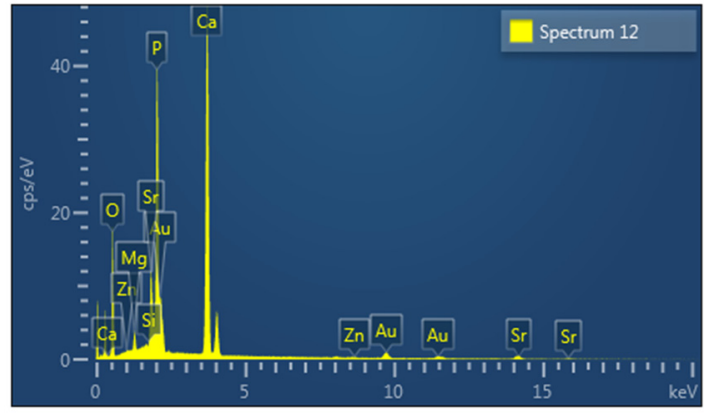

b.

Figure 4. SEM image (a) and EDX spectrum (b) of HAPc-Sr10; the bar in image (a) is $300 \mathrm{~nm}$. 


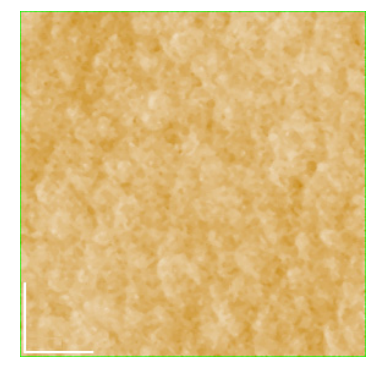

a

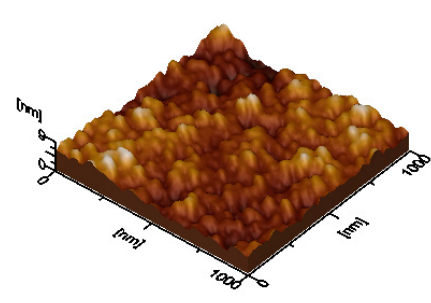

d

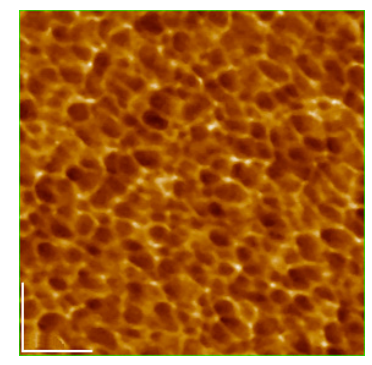

b

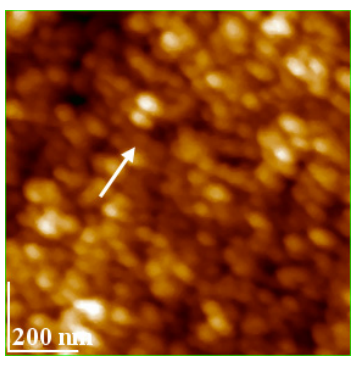

C

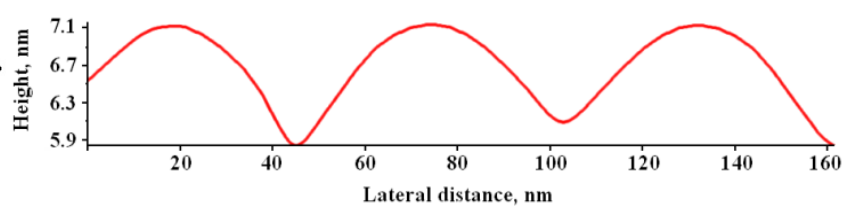

e

Figure 5. AFM images: 2D topography (a), phase (b), amplitude (c), 3D topography (d), cross section profile (e) for lyophilized HAPc-Sr5 powder, calcined at $300^{\circ} \mathrm{C}$, for $1 \mathrm{~h}$.

AFM images of lyophilized HAPc-Sr5 powders, calcined at $300^{\circ} \mathrm{C}$ for $1 \mathrm{~h}$, as self-assembled layer on glass are shown in Fig. 5. As remarked in 2D topography (Fig. 5a), phase image (Fig. 5b), amplitude image (Fig. 5c) and 3D-topography (Fig. 5d), the shape of particles is almost spherical with an average diameter of $38 \pm 3 \mathrm{~nm}$, also visualized in cross profile (Fig. 5e).

The HAPc-Sr5 layer shows a rather low surface roughness, expressed as root mean square, RMS of $1.23 \mathrm{~nm}$ given on scanned area, and $0.37 \mathrm{~nm}$ on cross profile.

AFM images displayed, for all calcined lyophilized powders, the average size of particles in the nanoscale range, showing that these biomaterials are formed from nanoparticles in very good agreement with TEM and SEM data.

\section{Behavior in water}

The content of the elements ( $\mathrm{Ca}, \mathrm{P}, \mathrm{Mg}, \mathrm{Sr}, \mathrm{Si})$ which were released from the solid samples immersed in ultrapure water for 1 day to 90 days is represented in Fig. 6 . The $\mathrm{Zn}$ content in the aqueous phase was below the limit of detection for all the samples. 
O. CADAR, R. BALINT, GH. TOMOAIA, D. FLOREA, I. PETEAN, A. MOCANU, O. HOROVITZ, M.T.-COTISEL

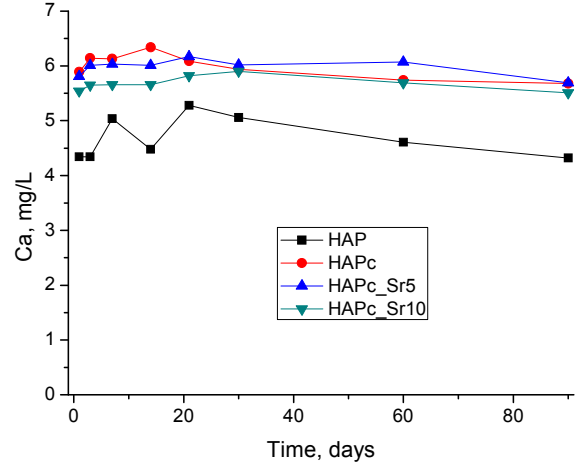

a.

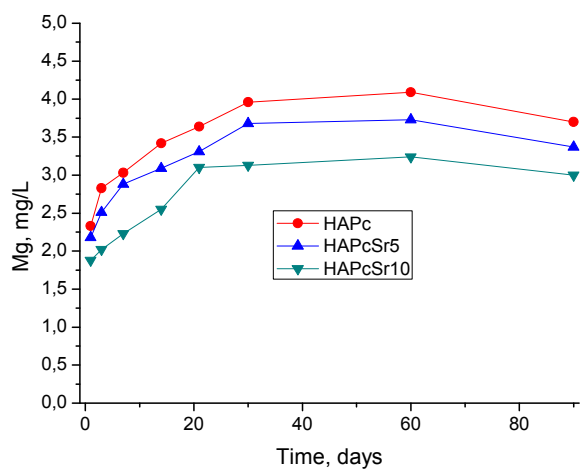

C.



b.

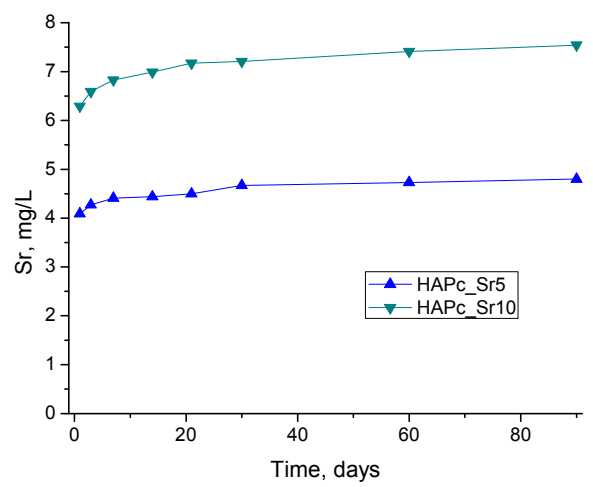

d.

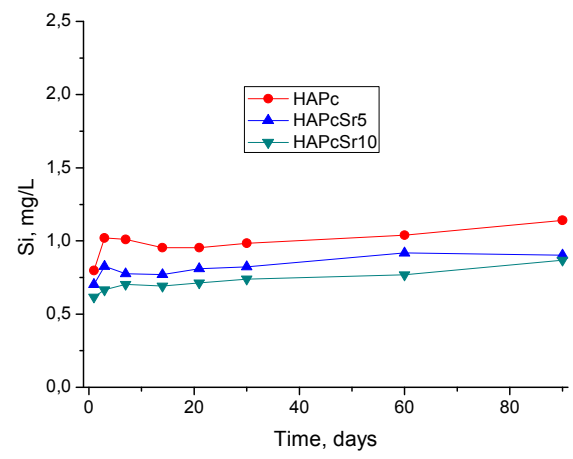

e.

Figure. 6. Calcium (a), phosphorus (b), magnesium (c), strontium (d), and silicon (e) release in water after immersion of HAPs samples for 1 - 90 days. 
The calcium content in solution (Fig. 6a) is low, because of the little solubility of HAP in water; it is practically constant in time, and so after the $1^{\text {st }}$ day the limit of solubility seems to be attained. For the substituted HAPs, the amount of $\mathrm{Ca}$ released is higher than from pure HAP, and very similar for all the complex HAPs.

The image is quite similar for $P$ release in water (Fig. 6b), but the difference between substituted HAPs and pure HAP is larger (except for the first 3 days). The P/Ca ratio in solution is higher than in the solid samples, which points out an incongruent dissolution process [24, 25].

The $\mathrm{Mg}$ release (Fig. $6 \mathrm{c}$ ) is increasing in time during the first 3-4 weeks, and then remains almost constant. The amount of Mg passed in the aqueous phase is disproportionately high as compared with its content in the solid samples. It is lower for the HAPc-Sr samples, denoting a stabilization of the complex HAP by the simultaneous presence of $\mathrm{Mg}$ and $\mathrm{Sr}$ [26].

The Sr release (Fig. 6d) is slowly increasing in time, and it is larger for a higher $\mathrm{Sr}$ content in the solid sample. Other investigations also showed that the solubility of $\mathrm{Sr}$ substituted HAPs increases continuously with increasing strontium content [27].

The Si content in the solution (Fig. 6e) is nearly constant in time after the first day; it is highest for HAPc and decreases with increasing $\mathrm{Sr}$ content. It is also higher than expected from the Si content in the samples.

\section{Behavior in SBF is illustrated in Figures 7a-e}

Ca (Fig. 7a) is initially removed from the SBF solution by the HAP and substituted HAP samples, but after the first days an equilibrium is established between solid HAP and solution. Two opposite processes determine the $\mathrm{Ca}^{2+}$ concentration in the solution, namely the uptake of $\mathrm{Ca}^{2+}$ ions to form a newly grown apatite lattice and the release of these ions. For complex HAPs the Ca content in the solution is lower than for simple HAP and continued to diminish slowly till the end of the testing period. This could be explained by an ionic exchange with the solution $\mathrm{Ca}^{2+}$ ions from SBF, which substitute $\mathrm{Mg}^{2+}$ and $\mathrm{Sr}^{2+}$ ions from the lattice. 
O. CADAR, R. BALINT, GH. TOMOAIA, D. FLOREA, I. PETEAN, A. MOCANU, O. HOROVITZ, M.T.-COTISEL

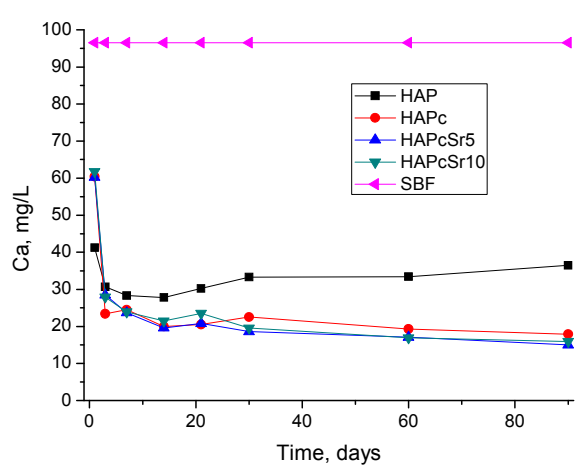

a.

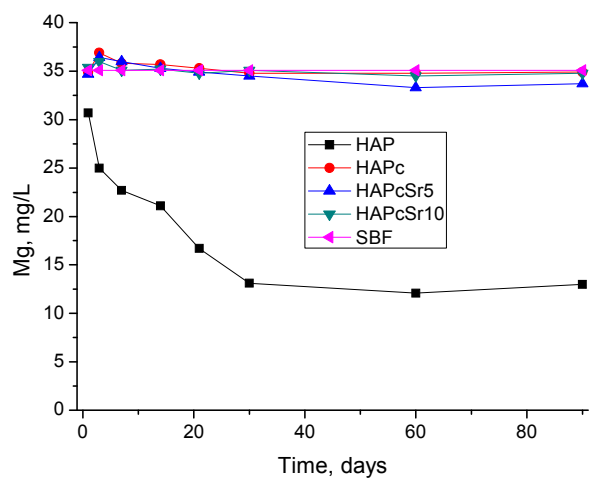

C.

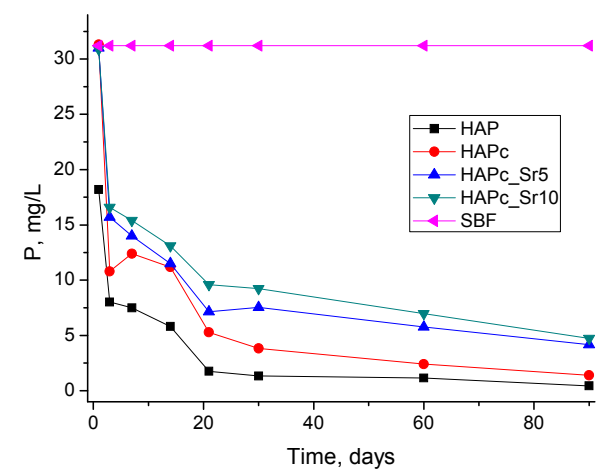

b.

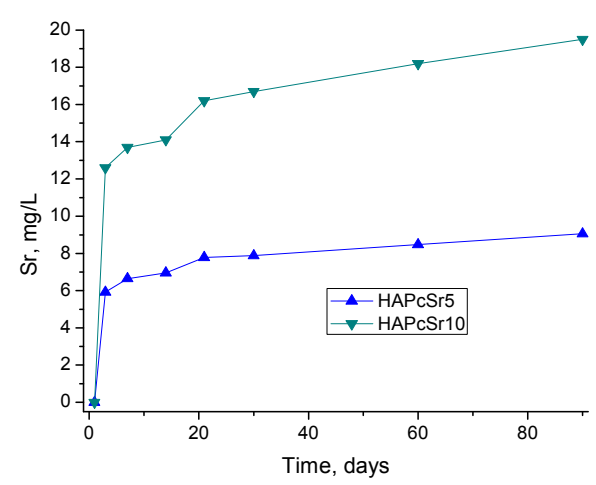

d

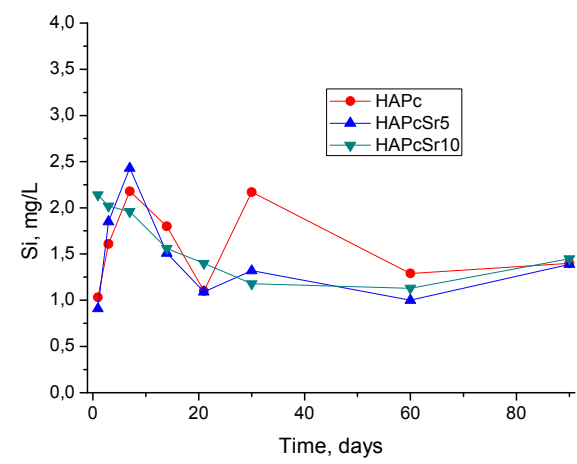

e.

Figure 7. Calcium (a), phosphorus (b), magnesium (c), strontium (d), and silicon (e) contents in SBF after immersion of HAPs samples for 1 day to 90 days. 
The phosphate content of the SBF (Fig. 7b) is almost totally used in the formation of new HAP lattice. For the substituted HAPs there is also a continuous diminution of the $P$ content in the solution, but it remains above that in presence of pure HAP, probably due to their increased solubility, with phosphate ions release

While Mg content in SBF (Fig. 7c) decreased in presence of HAP to a constant value after a month, for substituted HAPs the Mg content in the solution remains nearly constant. There is an uptake of $\mathrm{Mg}^{2+}$ ions to the HAP lattice, but for the complex HAPs with $1.5 \mathrm{wt} \% \mathrm{Mg}$ in the samples, this process is counterbalance by $\mathrm{Mg}$ release from the lattice and/or ionic exchange with the $\mathrm{Ca}^{2+}$ ions of SBF [28].

$\mathrm{Sr}$ (Fig. 7d) and Si (Fig. 7e) release in SBF present a similar trend as in water, but they are intensified, probably due to the ionic exchange with calcium, respectively phosphate ions from SBF. The increased release of $\mathrm{Sr}$ from HAPs in SBF was also observed in other samples [29].

\section{CONCLUSIONS}

The introduction of essential elements with important biological effects in nanostructured hydroxyapatite was proved by the physico-chemical investigations used in the present study. The multisubstituted HAPs presented an average degree of crystallinity and nanoparticle size pertaining to the nanoscale. The presence of $\mathrm{Mg}$ and $\mathrm{Zn}$ has a destabilizing effect on the HAP lattice, while the addition of $\mathrm{Sr}$ diminishes this effect. The release of their component elements was examined in aqueous solutions, as a model for biological liquids. The increased $\mathrm{Sr}$ concentration within HAP structure has significantly influenced the $\mathrm{Sr}$ release in both media: water and simulated body fluid. Notably, a different $\mathrm{Ca}, \mathrm{Mg}$ and $\mathrm{P}$ profile is determined in both media, and the formation of a new biomimetic hydroxyapatite is apparently promoted in SBF. The long time release observed for the valuable physiological elements contained in multisubstituted hydroxyapatites evidences a promising future of these biomaterials for biomedical purposes.

\section{EXPERIMENTAL SECTION}

Samples preparation: A solution containing the cations, and one containing the anions were prepared. The $0.25 \mathrm{M}$ cations solution contained $\mathrm{Ca}^{2+}$, and additionally for the complex HAPs: $\mathrm{Mg}^{2}, \mathrm{Zn}^{2}$, and $\mathrm{Sr}^{2+}$, according to the composition to be obtained. It was prepared by dissolving in ultrapure 
water the nitrates: $\mathrm{Ca}\left(\mathrm{NO}_{3}\right)_{2} \cdot 4 \mathrm{H}_{2} \mathrm{O}$ (Merck), $\mathrm{Mg}\left(\mathrm{NO}_{3}\right)_{2} \cdot 6 \mathrm{H}_{2} \mathrm{O}, \mathrm{Zn}\left(\mathrm{NO}_{3}\right)_{2} \cdot 6 \mathrm{H}_{2} \mathrm{O}$ and $\mathrm{Sr}\left(\mathrm{NO}_{3}\right)_{2}$ (all from Sigma-Aldrich). The $0.15 \mathrm{M}$ anions solution contained $\mathrm{PO}_{4}{ }^{3-}$, and (for the complex $\mathrm{HAPs}$ ) $\mathrm{SiO}_{4}{ }^{4-}$; it was obtained from diammonium hydrogen phosphate, $\left(\mathrm{NH}_{4}\right)_{2} \mathrm{HPO}_{4}$ (Sigma-Aldrich) and tetraethyl orthosilicate, TEOS, $\mathrm{Si}\left(\mathrm{OC}_{2} \mathrm{H}_{5}\right)_{4}(98 \%$, ALFA AESAR, Germany) in the adequate ratio. The working $\mathrm{pH}$ was 11.5 , fixed by adding a $25 \%$ ammonia solution (Merck).

The solutions were quickly mixed (equal volumes) at room temperature $22^{\circ} \mathrm{C}$, using a peristaltic pump and an impact reactor type " $\mathrm{Y}$ " for the two liquid flows [12, 14, 21, 30-34]. The obtained suspension was maturated in two stages: at $22^{\circ} \mathrm{C}$ for $24 \mathrm{~h}$, and at $70^{\circ} \mathrm{C}$, for other $24 \mathrm{~h}$, under intermittent stirring. The final precipitate was filtered and washed repeatedly with ultrapure water until nitrate free, at room temperature. It was dried by lyophilisation, and calcined at $300^{\circ} \mathrm{C}$ for one hour, and then disintegrated in a ball mill, to obtain a fine powder.

Samples characterization: X-Ray Diffraction (XRD) investigations were carried out using a DRON-3 diffractometer, in Bragg-Brentano geometry, equipped with a $\mathrm{X}$-ray tube with cobalt $\mathrm{K}_{\alpha}$ radiation, wavelength $1.79026 \AA$ ), $25 \mathrm{kV} / 20 \mathrm{~mA}$. FTIR spectra were measured on $\mathrm{KBr}$ pellets, containing the sample powders with a FTIR spectrometer JASCO 6100 in the $4000-400 \mathrm{~cm}^{-1}$ range of wave numbers, with a $4 \mathrm{~cm}^{-1}$ resolution.

The HAPs aqueous dispersions needed for TEM and AFM imaging were homogenized using a high-intensity ultrasonic processor Sonics Vibra-Cell, model VCX 750, for 5 minutes, at room temperature, $22^{\circ} \mathrm{C}$. Transmission electron microscope: TEM JEOL-JEM 1010 was used to determine the shape and the size of the phosphates nanoparticles. The samples were dispersed in deionized water, and the resulted colloidal dispersion was adsorbed on the TEM grids. For the examination with the scanning electron microscope, SEM Hitachi SU-8230, operated at $30 \mathrm{kV}$ was used. It is equipped with Oxford energy-dispersive X-ray spectrometer (EDS) for elemental analysis (EDX spectra). SEM grids are made of $\mathrm{Cu}$, covered by a carbon layer of 10 to $20 \mathrm{~nm}$ thickness. SEM samples were prepared by deposition of HAP samples, as powder, in thin layers on SEM grids The samples were gold sputtered in the AGAR, Auto Sputter Coater.

Atomic force microscopy (AFM) images were obtained using the AFM JEOL 4210 equipment, operated in tapping mode, using standard cantilevers with silicon nitride tips, with resonant frequency in the range of $200-300 \mathrm{kHz}$ and spring constant of $17.5 \mathrm{~N} / \mathrm{m}$ [35-45]. The particles were adsorbed from their aqueous dispersion on optically polished glass support.

Elements release tests: The $\mathrm{Ca}, \mathrm{P}, \mathrm{Si}$ and $\mathrm{Mg}$ amounts were measured in the solutions after immersion of $0.15 \mathrm{~g}$ of each sample in $15 \mathrm{~mL}$ ultrapure water, respectively Kokubo simulated body fluid (SBF) and incubation at $37^{\circ} \mathrm{C}$ in separated closed flasks for each sample/day. SBF solution as 
prepared according to Kokubo's SBF solution [46] having the composition $\left(\mathrm{mmol} / \mathrm{dm}^{3}\right): \mathrm{Na}^{+}$(142.0); $\mathrm{K}^{+}(5.0) ; \mathrm{Mg}^{2+}$ (1.5); $\mathrm{Ca}^{2+}$ (2.5); $\mathrm{Cl}^{-}(147.8) ; \mathrm{HCO}_{3}$ (4.2); $\mathrm{HPO}_{4}{ }^{2-}(1.0) ; \mathrm{SO}_{4}{ }^{2-}(0.5)$, and buffered at the physiologic $\mathrm{pH} 7.40$ at $37{ }^{\circ} \mathrm{C}$, with tris(hydroxymethyl)amino methane and hydrochloric acid. After 1, 3, 7, $14,21,30,60$, and 90 days, the supernatant (after centrifugation) was filtered $\mathrm{Ca}, \mathrm{Mg}, \mathrm{P}, \mathrm{Sr}, \mathrm{Zn}$ and $\mathrm{Si}$ contents in the filtrate were determined using an inductively coupled plasma optical emission spectrometer (ICP-OES) OPTIMA 3500 DV (Perkin-Elmer, USA). For calibration, multi-element standard solutions were prepared by the dilution of stock multi-element $1000 \mathrm{mg} / \mathrm{L}$ solutions Merck IV. All the experiments were performed in triplicate and the results were calculated as average values. The elements content in SBF solution without samples of hydroxyapatites was also measured in the same days, and the average value was calculated.

\section{ACKNOWLEDGMENTS}

Authors acknowledge the financial support from the Executive Agency for Higher Education, Research, Development and Innovation Funding (UEFISCDI) through grants no. 241 and no. 83 .

\section{REFERENCES}

1. D. Tadic, M. Epple, Biomaterials, (2004, 25, 987.

2. M. Figueiredo, J. Henriques, G. Martins, F. Guerra, F. Judas, H. Figueiredo, Journal of Biomedical Materials Research, 2009, 92B, 409.

3. M. Figueiredo, A. Fernando, G. Martins, J. Freitas, F. Judas, H. Figueiredo, Ceramics International, 2010, 36, 2383.

4. A. Bigi, E. Foresti, R. Gregorini, A. Ripamonti, N. Roveri, J.S. Shah, Calcified Tissue International, 1992, 50, 439.

5. B.S. Moonga, D.W. Dempster, Journal.of Bone and Mineral Research, 1995, 10, 453.

6. T.J. Webster, E.A. Massa-Schlueter, J.L. Smith, E.B. Slamovich, Biomaterials, 2004, 25, 2111.

7. F. Velard, D. Laurent-Maquin, J. Braux, C. Guillaume, S. Bouthors, E. Jallot, J.M. Nedelec, A. Belaaouaj, P. Laquerriere, Biomaterials, 2010, 31, 2001.

8. V. Stanic, S. Dimitrijevic, J. Antic-Stankovic, M. Mitric, B. Jokic, I.B. Plecas, S. Raicevic, Applied Surface Science, 2010, 256, 6083.

9. W. Querido, A.L. Rossi, M. Farina, Micron, 2016, 80, 122. 
10. A.S. Hurtel-Lemaire, R. Mentaverri, A. Caudrillier, F. Cournarie, A. Wattel, S. Kamel, E.F. Terwilliger, E.M. Brown, M. Brazier, Journal of Biological Chemistry, 2009, 284, 575.

11. A.L. Rossi, S. Moldovan, W. Querido, A. Rossi, J. Werckmann, O. Ersen, M. Farina, Micron, 2014, 56, 29.

12. G. Tomoaia, A. Mocanu, I. Vida-Simiti, N. Jumate, L.D. Bobos, O. Soritau, M. Tomoaia-Cotisel, Materials Science and Engineering: C, 2014, 37, 37.

13. A.F. Khan, M. Saleem, A. Afzal, A. Ali, A. Khan, A.R. Khan, Materials Science and Engineering $C, 2014,35,245$.

14. P.T. Frangopol, A. Mocanu, V. Almasan, C. Garbo, R. Balint, G. Borodi, I. Bratu, O. Horovitz, M. Tomoaia-Cotisel, Revue Roumaine de Chimie, 2016, $61,337$.

15. A. Bigi, G. Falini, E. Foresti, M. Gazzano, A. Ripmonti, N. Roveri, Acta Crystallographica Section B, 1996, 52, 87.

16. S. Nsar, A. Hassine, K. Bouzouita, Journal of Biomaterials and Nanobiotechnology, 2013, 4, 1.

17. I.V. Fadeev, L.I. Shvorneva, S.M. Barinov, V.P. Orlovskii, Inorganic Materials, 2003, 39, 947.

18. I. Cacciotti, A. Bianco, M. Lombardi, L. Montanaro, Journal of the European Ceramic Society, 2009, 29, 2969.

19. F. Ren, Y. Leng, R. Xin, X. Ge, Acta Biomaterialia. 2010, 6, 2787.

20. E. Boanini, M. Gazzano, A. Bigi, Acta Biomaterialia, 2010, 6, 1882.

21. C. Garbo, M. Sindilaru, A. Carlea, G. Tomoaia, V. Almasan, I. Petean, A. Mocanu, O. Horovitz, M. Tomoaia-Cotisel, Particulate Science and Technology, 2017, 35, 29.

22. E.S. Thian, J. Huang, M.E. Vickers, S,M. Best, Z.H. Barber, W. Bonfield, Journal of Materials Science, 2006, 41, 709

23. S. Gomes, J.M. Nedelec, E. Jallot, D. Sheptyakov, G. Renaudin, Crystal Growth and Design, 2011, 11, 4017.

24. A.N. Smith, A.M. Posner, J.P. Quirk, Journal of Colloid and Interface Science, 1974, 48, 442.

25. H.W. Kaufman, I. Kleinberg, Calcified Tissue International, 1979, 27143.

26. M.P. Moreira, G.D. de Almeida Soares, J. Dentzerc, K. Anselme, L.Á. de Sena, A. Kuznetsov, E. A. dos Santos, Materials Science and Engineering $C$, 2016, 61, 736.

27. H.B. Pan, Z.Y. Li, W.M. Lam, J.C. Wong, B.W. Darvell, K.D.K. Luk, W.W. Lu, Acta Biomaterialia, 2009, 5, 1678.

28. C. Stötzel, F.A. Müller, F. Reinert, F. Niederdraenk, J.E. Barralet, U. Gbureck, Colloids and Surfaces B: Biointerfaces, 2009, 74, 91.

29. J. Beuvelot, Y. Mauras, G. Mabilleau, H. Marchand-Libouban, D. Chapparda, Digest Journal of Nanomaterials and Biostructures, 2013, 8, 207.

30. A. Mocanu, R. Balint, C. Garbo, L. Timis, I. Petean, O. Horovitz, M. TomoaiaCotisel, Studia Universitatis Babes-Bolyai, Chemia, 2017, 62(2), Tom I, 95.

31. G. Tomoaia, A. Mocanu, L.-D. Bobos, L.-B. Pop, O. Horovitz, M. TomoaiaCotisel, Studia Universitatis Babes-Bolyai, Chemia, 2015, 60(3), 265-272. 
32. A. Mocanu, G. Furtos, S. Răpuntean, O. Horovitz, C. Flore, C. Garbo, A. Dănişteanu, G. Răpuntean, C. Prejmerean, M. Tomoaia-Cotisel, Applied Surface Science, 2014, 298, 225.

33. G. Tomoaia, O. Soritau, M. Tomoaia-Cotisel, L.-B. Pop, A. Pop, A. Mocanu, O. Horovitz, L.-D. Bobos, Powder Technology, 2013, 238, 99.

34. G. Tomoaia, M. Tomoaia-Cotisel, L.B. Pop, A. Pop, O. Horovitz, A. Mocanu, N. Jumate, L.-D. Bobos, Revue Roumaine de Chimie, 2011, 56, 1039.

35. A. Mocanu, R. Balint, C. Garbo, L. Timis, I. Petean, O. Horovitz, M. TomoaiaCotisel, Studia Universitatis Babes-Bolyai, Chemia, 2017, 62(2), Tom I, 95.

36. R.D. Pasca, G. Tomoaia, A. Mocanu, I. Petean, G.A. Paltinean, O. Soritau, M. Tomoaia-Cotisel, Studia Universitatis Babes-Bolyai, Chemia, 2015, 60(3), 257.

37. M.A. Naghiu, M. Gorea, E. Mutch, F. Kristaly, M. Tomoaia-Cotisel, Journal of Material Science and Technology, 2013, 29(7), 628.

38. A. Danistean, M. Gorea, A. Avram, S. Rapuntean, G. Tomoaia, A. Mocanu, C. Garbo, O. Horovitz, M. Tomoaia-Cotisel, Studia Universitatis Babes-Bolyai, Chemia, 2016, 61 (3), 275.

39. G. Tomoaia, O. Horovitz, A. Mocanu, A. Nita, A. Avram, C.P. Racz, O. Soritau, M. Cenariu, M. Tomoaia-Cotisel, Colloids and Surfaces B: Biointerfaces, 2015, 135, 726.

40. P.T. Frangopol. D.A. Cadenhead, G. Tomoaia, A. Mocanu, M. Tomoaia-Cotisel, Revue Roumaine de Chimie, 2015, 60(2-3), 265.

41. G. Furtos, M.A. Naghiu, H. Declercq, M. Gorea, C. Prejmerean, O. Pana, M. Tomoaia-Cotisel, Journal of Biomedical Materials Research Part B. Applied Biomaterials, 2016, 104, 1290.

42. M. Tomoaia-Cotisel, A. Mocanu, Revista de Chimie (Bucharest), 2008, 59, 1230.

43. O. Horovitz, G. Tomoaia, A. Mocanu, T. Yupsanis, M. Tomoaia-Cotisel, Gold Bulletin, 2007, 40 (4), 295.

44. M. Tomoaia-Cotisel, A. Tomoaia-Cotisel, T. Yupsanis, G. Tomoaia, I. Balea, A. Mocanu, Cs. Racz, Revue Roumaine de Chimie, 2006, 51 (12), 1181.

45. G. Tomoaia, A. Mocanu, L.D. Bobos, L.B. Pop, O. Horovitz, M. TomoaiaCotisel, Studia Universitatis. Babes-Bolyai, Chemia, 2015, 60 (3), 265.

46. T. Kokubo, H. Kushitani, S. Sakka, T. Kitsugi, T. Yamamuro, Journal of Biomedical Materials Research, 1990, 24, 721. 